Suggestions for an Inquiry into the Resources of the Empire: Discussion Author(s): George Taubman Goldie, George Watt, Scott Elliot, Major Close, Major Hills, Mr. FitzGerald, John W. Evans, George Goldie and Wyndham Dunstan

Source: The Geographical Journal, Vol. 27, No. 6 (Jun., 1906), pp. 558-566

Published by: geographicalj

Stable URL: http://www.jstor.org/stable/1776292

Accessed: 27-06-2016 04:39 UTC

Your use of the JSTOR archive indicates your acceptance of the Terms \& Conditions of Use, available at

http://about.jstor.org/terms

JSTOR is a not-for-profit service that helps scholars, researchers, and students discover, use, and build upon a wide range of content in a trusted digital archive. We use information technology and tools to increase productivity and facilitate new forms of scholarship. For more information about JSTOR, please contact support@jstor.org.

The Royal Geographical Society (with the Institute of British Geographers), Wiley are collaborating with JSTOR to digitize, preserve and extend access to The Geographical Journal 
or a detailed survey. 'Then it might be necessary to ask for help in surveying those unknown parts. No doubt a very large amount of assistance would be volunteered as soon as it was known that the Royal Geographical Society had undertaken such a task. The director would, of course, ask for help wherever it could possibly be given, and would be asked to report progress to the Research Department.

I am quite unaware if there are funds at the disposal of the committee for such purposes, and if there are such funds, I do not know their amount. But I do not think that there will be any lack of financial help when the character of the work is understood in the colony and at home. I am afraid a certain amount of obstruction would be encountered from those who already possess valuable special knowledge, and do not desire this to be generally accessible. Yet such obstruction from interested parties should not be an insuperable difficulty. Although I do feel the great importance of scientific geographical work of a highly technical nature, yet such an inquiry as this would be not only scientific, but of direct and immediate practical value. Its obvious practical advantage would bring the Society into closer touch with many prominent men both in the colonies and at home.

Before the paper, the Charrman : Mr. Scott Elliot is with us to-night to give us an address on a subject which is of rather unusual interest to the Society, and as I hope the paper will be followed by discussion, I will at once ask Mr. Scott Elliot to commence his address.

After the paper, the Chamman: Mr. Scott Elliot has made several very interesting suggestions which will no doubt lead to discussion, but I must ask you to remember the limitations of time. I will commence by asking Sir George Goldie to make a few remarks.

Sir Grorge 'laubman Goldie: I am glad to speak because, as President of the Society, I would like to show the value that I attach to a great deal that is in $\mathrm{Mr}$. Scott Elliot's paper. I agree with him in excluding India and Canada from our purview to-night, because in India there is the Government Survey, Forestry Department, and so forth; while in Canada there is the Geological Survey, which deals with various branches of science, and other similar institutions, which, I think, cover all that could at present be expected in the direction Mr. Elliot indicates. He mentions the want of maps in Natal during the war, and takes that as a basis for his thesis. I wish to say, having been on the War Commission, that there was a map of the north part as far as Ladysmith. It was not completed throughout Natal, owing to the difficulty of arranging with the Natal Government, which at the moment could not find the money for it. In those days, there was a feeling among some of the self-governing colonies, which one quite understands, of not liking to see independent survey work by officers from home. The Intelligence Department gave our commission an estimate as to what it would cost to make a survey of British Africa. They said that, if spread over twenty years, it would cost about $£ 90,000$ a year; that means about two millions altogether. It would not be a complete map, such as an œcologist or geologist would desire. We then asked what it would cost to survey all the unsurveyed portion of the British Empire; 
they told us about $£ 150,000$ a yeır, or in all thres millions. I wonder whether the present House of Commons would undertake that liability. It may be they would, and I certainly think we ought to press in that direction. We have to teach our compatriots that knowledge is economical, and ignorance very costly. The difficulty is how to get the public ear. Mr. Scott Elliot says that the public ought to know this and that, but how are you to reach them? Most people do not read advertisements; besides, they are costly. There are few things more difficult than to get a fact into the public mind. Mr. Scott Elliot told us that two of the great towns in the north of England are taking an interest in œcology. I need hardly say we sympathize with them, and applaud them. But I hope any results they obtain may be communicated quickly and freely to the Royal Geographical Society, so that there may be continuity of record and facility of reference.

$\mathrm{Mr}$. Scott Elliot hopes he is not alone in his desire for systematic exploration. I have been fifteen years on the Council of this Society, and I can vouch that we have been fully alive to the necessity of systematic exploration. I can assure Mr. Scott Elliot that the œcologists will be supported by this Society. But I should add that during the last half of the nineteenth century more attention was necessarily paid to extensive exploration; it could not be otherwise. I venture to say that, although Mr. Scott Elliot did admirable work when he went to Ruwenzori, he would never have had an opportunity of going if there had not been H. M. Stanley and others who preceded him. I endorse many of Mr. Scott Elliot's views, but I would point this out, that sone of them involve a great deal of expenditure. I should like to see the money spent, but we must obtain it first, and $I$ hope we shall have support in pressing the Government for a large increase of our present derisory grant from the State-a grant made half a century ago when we were an infant and unproved Society.

Sir Georae Wat'T: I did not expect you would call upon me to speak, becxuse my country (India) has been barred altogether from consideration. I have spent a considerable portion of my life in India, and what knowledge I possess on the subject of Mr. Srott Ellioi's lecture is entirely concerned with that country. However, I shall in a very few words endeavour to convey some of the ideas that have passed through my mind $b$ th in reading the paper and listening to the remarks Mr. Scott Elliot has made, since my personal knowledge of the subject may probably help, if any department, such as has been sketched out, is ever actually made in connection with any colony. We are not exactly ignorant of the subject of ocology in India. We have a great Survey Department, a Forest Department, an Agricultural Department, a Geological Survey, a Botanical Survey, a Zoological Survey, an Archæological Survey, and a Reporter on Economic Products, and all sorts of learned societies. Still we have not, strictly speaking, commenced the work Mr. Scott Elliot recommends; we are only in the stage of preliminary scientific exploration which, as has just been suggested, should precede œcology. By way of illustrating my meaning, I may give one or two examples. If you imagine the Ganges and the Brahmaputra severing India into an eastern section, which has now become the new province of Eastern Bengal and Assam, from a western-the rest of India-you have a division wbich is a very curious and natural one. The great waterway separates characteristic vegetations in a very remarkable manner. For instance, on crossing the Ganges, the first point that might strike an observer would be the comparative disappearance of leguminous trees. Oa the other side, the western side, the Acacix arabica is exceedingly prevalent; across the Ganges it becomes exceedingly rare. That is related to a series of other facts, and brings out an idea with regard to the province of Eastern Bengal and Assam which is unique almost in Indian experience. Had 
we gone into this subject carefully ycars ago, we might have seen that portions of Eastern Bengal and Assam were essentially countries for tea, and we should have saved no end of money and time had that idea come home to us. Eastern Bengal is essentially Chinese in its floral type. 'To be more correct, it is much closer to China than to India, and this comparison is not confined to its botany, but may be traced in its people, their customs, habits, and in some respects even their language, etc. For instance, in Eastern Bengal, the vegetable most largely grown, of the cabbage family, is a close ally to Chinese cabbage, and the original inhabitants, not the Bengali immigrants, all use vegetables which are often quite different frum thuse on the other side of the Ganges. For instance, a chrysanthemum is a common vegetable there, but nowhere exists on the other side of the Ganges. One might multiply illustrations innumerable in order to show that there is something more than mere latitude, climate, geological structure of soil, or even humidity; there is something we do not understand. Some years ago at this Society I was called upon to speak in connection with a paper which was read by Major McGregor on an exploration from Assam into Burma. I then made a remark that seemed to cause a little excitement to the late Sir Henry Yule, who was present at the meeting. I said there was something in the botany of the eastern side of India that we had not yet explained, and I gave illustrations in the behaviour of the rhododendrons. In Manipur and the Naga hills the selfsame species are found at much lower altitudes than in Sikkim. Is œcology likely to deal with such phenomena? If so, it will render a great service to the world. Some few years ago I wrote a little paper in the Agricultural Ledger on "Crops in Relation to Climate." It seemed to attract some attention in the United States of America, and I was called upon by the Government of India to follow the matter up further. The keynote of my observations was that humidity was in India apparently a more potent factor than temperature. I gave an illustration, namely, if you were to start at Lahore, say in June, and fly across India in one day to the extreme south, you would see the land being prepared for wheat, being sown with wheat; you would see the wheat germinating, mature, being reaped, threshed, and being carried to market. As a consequence of this, we possess in India, under each crop, a series of forms suited to a multitude of conditions that is perfectly bewildering. After the most careful consideration and consultation with experts interested, I drew up and issued to every collector and magistrate in India, a circular letter in which they were called upon to give me returns with regard to the sowing and reaping of certain crops. A list of the crops of which particulars were wanted was printed, and a table supplied like a census return, calling for the dates of normal and extreme sowings and reapings. The returns duly came back to me, and were so voluminous that they ran to a volume of over a thousand pages. We are still, after five or six years, working at these returns, and hope, probably in the next ten years, to be in a position to publish the Report. Such, then, is one out of the many examples of œcological research that we in India have been endeavouring to prosecute, and such inquiries will have to be faced if Mr. Scott Elliot's theories are to be put to a final and practical test. I am afraid I should detain you too long to go into more illustrations, therefore I will only venture to add one or two words. Mr. Scott Elliot referred to a poisonous bean. I was one of the first of mcdern writers to draw attention to that subject. Of course it has been known from time immemorial, that the Lathyrus sativus pea, if eaten continuously for some time, will cause paralysis of the lower extremities. But a new feature seems to have arisen. A bean sent to England, which I believe to be Phaseolus lunatus, is said to have proved poisonous. Before accepting this view I should prefer to think there was a mistake somewhere, as the cultivated bean in question 
has never before been suspected to be anything but perfectly wholesome. I will not say anything more, except to express my regret that this Society should say, if it does finally say, that India should be excluded. If we are going to have any such inquiry at all, let India be included by all means, and our scientific men will welcome a helping and encouraging hand. But we have nothing like the organization that would be indispensable to conduct an cecological survey. We should want an army of observers and workers that Government will, I fear, never give us unless a strong case can be made out for this new departure. By excluding us you are nct giving us a helping hand, and we want the Royal Geographical Society to say this work is an important piece of work which should be done in India as well as in every other country, if such be the final opinion.

Mr. ScotT Elliot : I have pleasure in testifying to the tremendous help Sir George Watt's dictionary has been to me in all my scientific work. I thank you very heartily.

Major Close : I think we are much indebted to Mr. Scott Elliot for having brought this subject to notice again. I wish to make a few remarks from the point of view of the official world. It is true that the only map we had of South Africa was of a little triangular bit of the north of Natal, and the reasons for that are reasons which I must not advert to. Perhaps it would be interesting if I say what is going on in Africa at the present moment, because I do not think the lecturer knows what is going on. We have a Survey Department properly organized on the Gold Coast. They have funds at their disposal, and the work is of a very accurate character. Next, we have a survey proceeding in the Orange River Colony, which, though perhaps not quite so rigorous, is sufficiently rigorous for the purpose of making a map on the scale mentioned by Mr. Scott Elliot. The scale it is actually working on is 2 miles to the inch, and they are turning out about 10,000 square miles a year. A survey has been approved of on systematic lines for British East Africa, and the organization of that is proceeding, and a commencement will be made in April next. The survey of Southern Nigeria and Lagos is to be systematized. Excellent work is being done in Uganda. The net result of all this is, that under instructions from the Colonial Office, the local governments in Africa are at the present moment spending over $£ 40,000$ a year, but since these surveys have only been commenced quite recently, it is too soon to expect many results just yet. We shall see those results in a few years. Most of these areas I have been speaking of were either crown colonies or protectorates - that is to say, colonies administered from home. But a self-governing colony runs its own show. If this Society could persuade the self-governing colonies in Africa, if it could persuade Natal to undertake a systematic survey, it would be of the greatest possible value to soldiers. The War Office has for many years past done its very best to encourage the mapping of the empire. No effort has ever been wanting on the part of the War Office to get maps made. Mr. Scott Elliot mentioned the question of scales. He said, "The first step is to get a map of the particular colony selected on a scale which will satisfy the War Office." The War Office will be satisfied with a scale of 2 or 4 miles to the inch, according to circumstances; or say $1: 125,000$ or $1: 250,000$. I do not know whether we have any definite proposition before the Research Committee, but if there is a definite proposition, it seems to me to be that the Society should undertake the exploration of either a portion of Rhodesia or Zululand. I think it would be a very excellent thing if the Society were to undertake the former.

Major Hills : I should like to make two or three remarks upon this subject. First of all, with regard to the general question of mapping the British possessions, I think that Mr. Sco't Elliot has been unduly optimistic in his statements, because

$$
\text { No. VI._JunE, 1906.] }
$$


he said that he thought that, though there were only very few maps published by the Intelligence Department of the War Office, they had probably a very large secret stock of maps. Now, I think I may say without divulging any official confidence that these secret stocks do not exist. The whole question of the maps was gone into before the war commission which Sir George Goldie has already quoted, and has been made public, and it would be only in the nature of a dangerous delusion for people to suppose that the War Office holds large numbers of secret maps which are not issued. As regards the general question which is before this meeting, I must confess I have rather a vague idea as to what the actual proposition is. It seems quite hopeless to suppose that the Snciety could do any perceptible amount of survey work. 'The President has given figures showing the cost of a survey of the British Empire or British possessions in Africa, and anybody who looks at those figures will see that a Society which has not many thousands a year to spend could not make great progress. Take, for instance, another example as illustrating this point. The Survey Department of India-that is, only the Trigonometrical and Topographical Surveys, independent of the Botanical, Mineralogical, and Geological Surveys, cost about a quarter of a million a year, and if you look at the area of India, you will see that you will have to multiply that sum several times over if you are going to do the whole empire on the same sort of scale. I do not see what the Suciety can do, even with a small country such as Zululand. They cannot carry out a survey of this nature-topographical, botanical, and geological-so as to complete it within any reasonable period of years. It seems to me that the right line of action for the Society is to bring pressure to bear upon the Government to spend more money upon the survey of the empire. I am going to say a thing which may be rather unpopular, but I really think it would be better if the Society, so to say, stuck to its own last and did not go outside the geographical question. I think if we go beyond that and enter into these commercial questions, questions relating to the economic vegetation of the country, or the geology or the mineralogy, we shall get beyond our legitimate sphere, which is the study of scientific geography. We are, I take it, not a commercial Society, and I think we had better not go intı questions which are so directly commercial in their bearing. Our rôle in this matter is to make public as often and in as many directions as possible, the want of geographical surveys of the empire, and to lose no opportunity of impressing upon the Government and upon all public men the urgent necessity of carrying them out.

Mr. FitzGerald : It has given me great pleasure to be present to hear Mr. Scott Elliot's remarks on a subject that should appeal to every one interested in the development of the commercial resources of our empire. I believe, however, the Imperial Institute does take up this subject, and that one can obtain information there, not only as regards products, but all Government publications as well. I am very glad that this subject has been ventilated, because there is no question more important than the increase of our knowledge of commercial geography. It is one in which I have always taken a very great interest, but, as Sir George Goldie has truly remarked, it is a most difficult matter to get the people of this country to evince the interest they should in this important question. I can speak from personal knowledge as to this, and I will give an instance in point. I gave some lectures last year in Lancashire on the great possibilities of the Sudan as a cotton-growing country. On one occasion a gentle nan who was present came up after the lecture and expressed his astonishment that the Blue Nile was in the Sudan! I need not point out that the Blue Nile valley is one of its richest parts.

The Blue Books and reports that are published annually on the various parts 
of our empire contain often most valuable information. They appear, are read by a select few, and then pass into undeserved oblivion, and it has always been a matter of great regret to me that the information they contain could not be gathered together and brought up to date. For instance, an administrator, on first going out to one of our comparatively new tropical possessions, spends a good deal of his own and his country's valuable time in obtaining information that is already available. Had he only been able to take out with him a condensed summary of the reports issued by his predecessors as to the capabilities and possibilities of the country, how much more valuable his own first report would be! I earnestly hope that the suggestion which has been advocated by Mr. Scott Elliot will be considered and not allowed to rest, and that the eminent gentlemen who are present will bring their knowledge and experience to bear upon it so that some definite and permanent result may be attained.

Dr. John W. Evans: I rise to say a few words about what is being done at the Imperial Institute in the direction which has been advocated by Mr. Scott Elliot. Prof. Dunstan, the Director, intended to be present, but he was detained at the last moment, and I must do my best to replace him.

In the first place, it is not enough to send out an expedition to survey a colony still comparatively undeveloped. It is impossible for even the most skilled specialists to investigate satisfactorily the problems that present themselves, and which are important for the determination of the lines on which the colony may be best developed, unless they have at their disposal the resources with which science has supplied us, and that are only fully available in technical establishments such as the Imperial Institute. It is not enough to report that iron or lead or manganese is present in considerable amount; the value of a deposit of iron or manganese is affected by minute amounts of certain impurities, while the question whether lead ore can be worked at a profit depends largely on the presence of a few ounces of silver in the ton. In regions that appear capable of agricultural devclopment, the soil requires careful examination and analysis, and vegetable products, such as rubber, fibre, and essential oils, can only be properly investigated in adequately equipped laboratories. Not only have we the laboratories, but there is a staff of some two score of chemists, mineralogists, and botanists who are fully competent to deal with such questions as may arise. As Sir George Watt has referred to the subject of poisonous fodder plants, I may mention that we have already examined a number of these from different localities; the constituents have been determined, and, as far as possible, we have endeavoured to ascertain why this variety or that is poisonous, and in this connection have been supplied with detailed information as to the conditions under which they were grown (Dunstan and Henry, Proc. Roy. Soc., 1901-04).

Besides examining the mineral and vegetable products forwarded to us, we have sent out specialists to make observations and gather materials. Three years ago Mr. Parkinson, a geologist of high reputation and a Fellow of this Society, and Mr. Huddart, a skilled mining engineer, commenced the mineral survey of Southern Nigeria and Lagos, which is still proceeding. They carry on exploration in the colony in the dry weather, and in the wet season they work out at the Imperial Institute their notes and specimens, the latter having meantime been analyzed by the chemists. Already results of importance have been obtained-deposits of coal, pitch, tin, and the mineral monazite, which furnishes thoria for our gas mantles, have been studied, and at the same time assistance has been afforded to the topographical survey. More recently a mineral survey has been organized in Northern Nigeria on similar lines under Mr. Falconer, formerly chief assistant to Prof. James Geikie. 
Another member of our staff, Mr. Freeman, a well-known botanist, has also spent some time in Nigeria, and the materials he brought back have been investigated at the Imperial Institute. Still another, Mr. H. Brown, a chemist who has devoted special attention to rubber, visited the Bahr el Ghaza, and investigated the possibility of developing the rubber and other natural resources of the province. Again, Mr. Coomaraswanny, an able geologist, is working with an assistant in Ceylon, where the new mineral thorianite-far richer than monazite in thoriahas been discovered as the result of analyses at the Imperial Institute. At the present moment negotiations are in progress for other expeditions, and there seems no limit to the work that may be done if we are properly supported with funds.

I may add that the library of the Imperial Institute is well supplied with literature relating to the British colonies and dependencies, and we do our best to keep it up to date.

Sir GEorge GoLdie: Lest there should be any misunderstanding, I should like to say the Council of the Royal Geographical Society made a representation at the same time as the Royal Society. I shall not reply in detail to the remarks made with regard to the sphere of the Royal Geographical Society. That depends upon the question--what is geography?

The Chairman : It appears to me that the two questions before us to-night are, firstly, the possibility of putting more varied information ou our maps than they contain already, which I think is one which will require much consideration. 'l'here is, for instance, a great deal of botanical information which obviously it would be impossible to include in any map whatever. And, secondly, whether the Society should assist in any way to the better distribution of such information as we possess. I agree with Sir George Goldie that it is exceedingly difticult to persuade people that they can get information if they only ask for it. As a matter of fact, between the Colonial Institute and the Royal Geographical Society, I take it that any explorer might equip himself with pretty nearly all the information he requires; but it is very necessary to advertise this fact, and I think that we might possibly do a little more than we are already doing towards making it known where the real sources of information lie. We ought seriously to consider whether we cannot give some practical outcome to the suggestions which have been made. What can the Society really do? I think that we might form a committee of the Research Department to consider in what direction we can work with the best chances of success, both as to making information known to those who require it, and as to giving assistance towards producing an economic map. We might try the experiment which Major Close has suggested, and see what comes of it. As regards Major Hills' remark that one quarter of a million is spent on the Survey of India, and his conclusion that it would require a very enormous expenditure to survey the whole of the empire, I do not think Mr. Scott Elliot proposes for an instant that all the empire should be surveyed as India has been surveyed. There are all sorts of surveys in India-geographical surveys, topographical surveys, trigonometrical and revenue surveys, which latter reach the scale of 24 inches to the mile. The first cost of making a geographical map is, I consider, nothing that sbould be prohibitive, even if we consider such a large question as the empire as a whole. I have had considerable experience in framing estimates for surveys of that class, and certainly should have thought it would not have cost nearly as much as the amount suggested by Sir George Goldie.

Sir George Goldie: I did not say it; that was the evidence put before us.

The Chairman: I should have thought it would have cost perhaps half of that. I. will now ask Mr. Scott Elliot to reply to some of the criticisms that have been 
offered to his paper, and then we must conclude by thanking him for giving us such a very interesting afternoon.

Mr. Scote Elliot : I must thank you very sincerely for the encouraging support which I have received from almost everybody who has spoken. First of all, with regard to expeditions of the Imperial Institute and of the Intelligence Department of the War Office. The more there are, the better I shall be pleased. But I wish earnestly to bring before the Research Department a very definite and distinct proposal that the Royal Geographical Society should itself undertake some colony and do it on these modern lines. There is, first of all, the difficulty of cost, but I would like to point out that if the Society were to approach any colony in the right spirit, and show that we simply wished to assist them to carry out a scientific survey, I fail to see where such a colony could find a reason for objecting. Then there is the difficulty of interesting the public. Now, some remarks of the last speaker explain precisely where that difficulty comes in. If we can make the public understand and realize that points of practical and commercial importance are solved by scientific treatment, then we shall no longer have any difficulty in interesting everybody. But there is a tendency in the science of this country to adopt an c soteric spirit, and to cut itself aloof from practical life, and then of course the public says that it cannot be bothered by scientific matters which do not explain anytbing that it wishes to know. I think our Scciety should most certainly keep in touch with practical men. I sincerely hope that the Research Committee will choose some colony, so that we can show what we can do when we have the chance of doing work on the very best modern scale.

Prof. Wyndham Dunstan, F.R.s., Director of the Imperial Institute, who was unable to be present, has written the following remarks :-

The valuable suggestion of Mr. Scott Elliot, that a systematic survey of the undeveloped portions of our empire should be undertaken in turn, is one which I hope will not be lost sight of. What is required is a definite scheme of operations determined upon by the various societies and bodies interested. We require a topographical survey, and a survey of the vegetable and mineral resources, of the climate and sanitary conditions of each of the regions, chiefly directed to the end of opening up these countries for the development of trade and commerce. Funds are required, but it will not be questioned nowadays that the cost of work of this character should be undertaken by Government. Large sums of money are annually expended on the administration of these countries, but until recently little or nothing has been expended in this economic work, which is a necessary preliminary to commercial development. The department chiefly concerned is the Colonial Office, under whose auspices the work could be best undertaken.

It is, however, obvious that such surveys will have little result unless the collected materials, vegetable and mineral, are submitted to full examination, especially from the chemical side, and then commercially valued and brought to the notice of the commercial community. By this means only will the expenditure be fully justified in the eyes of the Government, and a certain return in the shape of revenue secured.

An organization for accomplishing this working up of materials now exists, as Dr. Evans has pointed out, at the Imperial Institute. It deserves to be better known, and more liberally supported with funds. Wbat it has accomplished in the last few years may be learned from its 'Bulletin' and published reports. Its work is carried on in close co-operation with the Colonial Office and the Colonial Governments concerned, but its permanent staff, numbering between thirty and forty skilled workers, is so small for the work it is called upon to do that but few of its members can be spard for the work of exploration on the spot which is so 
necessary. Six men are, however, so engaged in the colonies at the present time, and it may be said that the economic survey of British West Africa is already well in hand. The Imperial Institute suppliez the nucleus and permanent staff for dealing with the results of these surveys and this work, which can only be properly conducted in London. It remains to determine how the scheme of surveys is best arranged.

Through the Colonial Office as the controlling body, with the co-operation of the Royal Geographical Society, the London School of Tropical Medicine, and the Imperial Institute, an efficient plan of operations ought to be easy to arrange. But the ground to be covered is enormous, and, as Mr. Scott Elliot suggests, it will be prudent to take one country at a time. Personally, for many reasons, I should be inclined towards the selection of West Africa for the first action, and that because so much is already arranged on the proper lines for the initial development of that vast country.

[Prof. Wyndham Dunstan's support of my suggestions is extremely gratifying, and the Imperial Institute would be of an inestimable assistance to the survey. Yet I must protest strongly against his view that either the Colonial Office or the Imperial Institute could possibly conduct such a survey so well as the Royal Geographical Society. The Colonial Office has in the past, and will no doubt in the future, continue surveying and reporting, but no Government office could possibly undertake or control work of this nature. Otherwise such work would have been done long ago.-G. F. S. E.]

\section{BATHYMETRICAL SURVEY OF THE FRESH-WATER LOCHS OF SCOTLAND.*}

Under the Direction of Sir JOHN MURRAY, K.C.B., F.R.S., D.Sc., etc., and LAURENCE PULLAR, F.R.S.E.

\section{Part XI.-The Lochs of the Beauly Basin.}

THE Beauly basin is an important and extensive one, extending across almost the entire width of Scotland, from Beauly firth on the east coast to within about 4 miles from the shores of Loch Duich, and about 6 miles from the shores of Loch Carron, on the west coast. The basin is situated in a very mountainous district, many of the peaks in the central and western part of the basin exceeding 3000 feet, and some of them approaching 4000 feet, in height, while on proceeding eastward towards the outlet of the basin the land becomes gradually less elevated. On the southern boundary of the basin are Tigh Mor (3222 feet), Sgùrr nan Conbhairean (3634 feet), Garbh Leac (3673 feet), Sgùrr nan Ceathramhan (3614 feet), Ciste Dhubh (3218 feet), Carn Fuaraloch (3241 feet), and Sgùrr a' Bhealaich Dheirg (3378 feet); on the western boundary Beinn Fhada (Ben Attow), 3383 feet, Sgùrr nan

\footnotetext{
* Plates, p. 656.
} 